\section{Hearing aids and services for developing countries ${ }^{1}$}

Key words: Hearing, deafness, disabilities, guidelines.

\footnotetext{
Based on: World Health Organization. Guidelines for hearing aids and services for developing countries. Geneva: WHO; 2001. Available from: http://www.who.int/pbd/pdh/pdh_home.htm [Internet site]. Accessed 1 August 2001. (WHO document PBD/PDHI/01.1).
}

Of the estimated 250 million people around the world who have hearing loss and could benefit from having a hearing aid, two-thirds of them live in developing countries. In adults hearing loss affects their ability to obtain, perform, and keep a job. Throughout life, hearing loss causes people to be isolated and stigmatized.

And while hearing loss is generally associated with aging, people in the developing world are more susceptible to this problem at a young age. Hearing loss in children affects language formation and cognitive and social development, and it can lead to lifelong disability.

Because of the increase in world population and lengthening life expectancy, the number of persons with disabling hearing impairments is expected to progressively and substantially increase in the future unless decisive public health action is taken. In developing countries, where there is a strong need for trained people to increase productivity, hearing impairments can hinder a community's economic development.

In spite of the pressing needs in the developing world, the supply of hearing aids falls far short of the demand. Of the hearing aids that are manufactured in the world, only a tiny proportion of them end up going to developing countries-only about one out of every eight units produced. Of the ones that do go to developing nations, most are far too expensive for the average consumer, typically costing from US\$ 200 to over US\$ 500. Further, there is a major shortage of services in developing countries to fit hearing aids correctly, and with very few trained personnel to help in that process.

In response to this situation, the World Health Organization (WHO) has taken a number of steps. For example, representatives at a 1998 workshop organized by WHO and the Christian Blind Mission recommended that a small working group draw up guidelines for requirements for hearing aids and their accessories and services so that they would be appropriate and affordable for developing countries. The resulting guidelines were released at a meeting held in Geneva 11-12 July of this year.

The new guidelines provide detailed requirements for the manufacture of affordable and appropriate hearing aids, the provision of services, and the training of personnel in developing countries. The guidelines are particularly targeted at manu- 
facturers, distributors, policymakers, and service providers at all levels. It is intended that the hearing aid requirements in the guidelines would enable manufacturers to produce them at low cost and in bulk with currently available technology. It is hoped that by implementing the guidelines the prices for hearing aids could be reduced to as little as US\$ 10 to US $\$ 20$ each.

Children with moderate or severe hearing impairment in the better ear should receive priority, followed by adults, according to the new guidelines.

\section{HEARING AID REQUIREMENTS}

In terms of hearing aid requirements, one of the key recommendation made by the working group was that hearing aids worn behind the ear are likely to be the preferred option for most situations in developing countries. However, aids of the modular type worn in the ear may have potential use, and there will also be a need for body-worn aids in some areas. The group felt that body-worn aids would only be necessary where the needs they serve (low cost, ease of repair, wide availability of batteries) are not better met by other hearing aids. For example, this would be the case in rural areas of some developing countries where body-worn aids are now generally preferred.

Manufacture, or assembly and servicing, should be feasible in developing countries. Hearing aids should be constructed in a form that allows for ease of servicing and with components that are readily available and will remain so for a period of at least 5 years. Manufacturers should provide sufficient technical details, including circuit diagrams, to permit servicing to take place in appropriate centers in developing countries.

Hearing aids should be capable of operating within the specified performance over at least the temperature range $5{ }^{\circ} \mathrm{C}$ to $45^{\circ} \mathrm{C}$ and a humidity range of $0 \%$ to $80 \%$.

Aids should have the means to reduce the gain at audio frequencies below 750 hertz $(\mathrm{Hz})$. A reduction of at least 12 decibels $(\mathrm{dB})$ at $250 \mathrm{~Hz}$, relative to $750 \mathrm{~Hz}$, should be achieved by either a preset or a user control. The volume control should have a range of at least $30 \mathrm{~dB}$ and be clearly numbered.

The hearing aid should be designed so that the risk of injury or discomfort to the user is minimized. The external parts of the hearing aid should not have any sharp edges or protrusions and should be made of materials that minimize the risk of allergic skin reactions. The external parts should be made of durable materials and designed and finished in a way that minimizes the noise caused by wind or physical contact. Manufacturers should provide hearing aids in a few basic colors as requested by the country involved. The color range could include skin colors, or hair colors such as black or gray.

The number of moving parts should be minimized. The working group considered but rejected the idea of omitting the on/off switch and just having the user remove the battery when the hearing aid was not being worn. It is difficult to make a simple and effective battery drawer act as an on/off switch, and the loose batteries could more easily be lost and be tempting for a young child to swallow. The battery compartment should be designed so that the battery can only be inserted with the correct polarity.

In order to avoid being assessed import duties and further increasing their price, hearing aids should be classified as a medical device. While this is now done in most developed countries, it is less common in developing nations.

\section{Earmolds}

The earmold is an integral part of the hearing aid system. Individual earmolds should be produced from impressions of the ear taken at the primary care level using a syringe technique. Where no earmold manufacturing facilities are available, a range of universal (stock size) earmolds may be used as a temporary measure.

Readily accessible earmold manufacturing facilities must be established as soon as possible to produce earmolds, using two stages: 1) making a cast of the ear impression using plaster of paris (partly dehydrated gypsum) or gel and 2) filling the cast with the acrylic- or silicone-based earmold material.

Initially, earmold laboratories should be set up centrally to serve a district, region, or country, depending on demand. Central laboratories can only be effective where there is a good network to bring ear impressions to the laboratory and return finished earmolds to the hearing aid user. When the situation permits, either stationary or mobile earmold laboratories should be set up at the district (secondary) level. Ear impressions need to be brought to the laboratory quickly since shrinkage occurs after a few days. Such centralized laboratories can be set up to produce a larger range of earmold styles of various materials. Initially, it may be possible to train a local dental technician and house the earmold-making facility in a dental laboratory.

Alternatively, simpler, portable earmold-making facilities can be established. The equipment and materials can be transported to where the earmolds are required. However, the range of earmold styles 
and the materials used with this method are limited. This method is recommended for more inaccessible regions without electricity, or where a central earmold laboratory has not yet been established.

Some equipment needed to manufacture earmolds can be bought in developing countries from electronics or dental suppliers. Other equipment needs to be imported from specialist earmold suppliers in developed countries. A long-term supply of materials needs to be ensured when setting up earmold laboratories.

Earmolds should, if possible, be replaced at the following intervals: for infants and young children, every 3 to 6 months; for older children, every 6 to 12 months; for adults, every 2 to 3 years. The need for replacement also depends on the style and material of the earmold. A leaking, hurting, or broken earmold should be replaced as soon as possible.

\section{Batteries}

The availability of a reliable supply of batteries is essential to the continuing use of hearing aids. Most hearing aid batteries now need to be imported from developed countries. This should be done dutyfree, such as by countries reclassifying them as medical instruments rather than electronic consumables.

Batteries may be of the usual disposable type that are replaced when they are run down. Rechargeable batteries may be appropriate for many countries. These will last for at least a year, but they have to be used in conjunction with a source of electrical energy to charge them.

\section{SERVICES}

Services and their delivery can be divided into four main categories: raising awareness, identification and assessment, provision of hearing aids, and support for users. These categories are all interlinked and dependent on each other.

\section{Raising awareness}

Awareness of hearing impairment and how to prevent and deal with it needs to be raised and promoted in many groups in society. Using a hearing aid should be encouraged as one of the potential solutions; the subsequent demand will help to create a market that will sustain rehabilitation needs.

The prime messages for raising awareness and health promotion are the same for all target groups, but they need to be specifically adapted and targeted for each group. The targets for these messages include: society in general; people with hearing impairment; parents and teachers; community and national leaders; professional providers of health care, especially community health and rehabilitation workers; providers of educational, social, and vocational services; and policymakers.

An awareness program on hearing impairment may be part of a larger program for disability prevention that has a bigger target population. A variety of health education materials should be developed and different media utilized according to the group being targeted. Training in awarenessraising should be given for all professional care providers, including community health workers. Material to be presented by the primary level worker should mainly be verbal, supported by other methods used and understood by the community such as pictures, booklets, video or TV, and sign language.

\section{Identification and assessment}

A simple and straightforward identification procedure is useful to allocate the person presenting at a health center or for screening each member of a target population into one of four groups: 1) hearing problem and discernible ear disease that is treatable by medical and/or surgical means, 2) hearing problem and no such ear disease, 3) such ear disease and no hearing problem, and 4) no such ear disease and no hearing problem.

The identification procedure should include a short questionnaire concerning ear and hearing health; an ear examination, preferably with an otoscope; a simple hearing test, whose performance characteristics are known and proven; and, for infants, a questionnaire to parents regarding development of speech and response to sound, or, for adults, a voice test.

Following identification, an assessment of hearing function is required. This assessment should be carried out at the secondary level, when these facilities and personnel are available. When secondary level facilities are not available, primary level workers should be trained to carry out hearing assessments. Facilities may be shared amongst a group of communities or take the form of mobile services.

Hearing assessment should include: brief case history; ear, nose, and throat specialist assessment if available, or assessment by a medical officer if not; frequency-specific test of hearing threshold level in each ear; shape, degree, classification, and cause of hearing loss; interpretation of hearing test results and decision whether hearing aid would be beneficial; and referral to other needed services. 
Reassessment should be carried out every few months in children (depending on age of the child), and after $4-5$ years in adults (the general life-span of a hearing aid).

\section{Provision of hearing aids}

Prior to services being set up to fit users with hearing aids, a reliable source of supply must be established for the hearing aids themselves as well as for batteries, earmold materials, and spare parts and repair materials.

If hearing aids are to be imported, then a reliable and safe method of shipment is required that allows all items to enter the country without being detained at customs. Shipment can be done in bulk. Hearing aids should be checked after arrival in country and before being fitted to the user. Sufficient stocks of all items should be kept in order to meet the demand and thus minimize the time between assessment and fitting and the time required for repair or replacement.

The process by which a hearing aid reaches its eventual wearer varies depending on whether the distribution service is completely State operated, under conditions controlled by the State, or under a completely private system.

To reduce costs, hearing aids can be purchased in bulk. Hearing aids and services for them should be provided to users at a price that they can afford. Governments of some developing countries may agree to share in the costs of hearing aids and services or provide them free. A low-cost hearing aid should be carefully marketed, especially in countries where more sophisticated models are already available. Affordable hearing aids must not be made available to unscrupulous individuals who may sell them to users for large profits.

Hearing aids should only be fitted following a hearing assessment. A hearing aid should be fitted together with an earmold, some batteries, a case for the hearing aid, a dehydrating agent to prevent moisture corroding the hearing aid and battery, and simple instructions in pictures and text. Young children should be provided with a suitable harness for bodyworn aids to prevent the aid from being dropped.

The actual fitting of the hearing aid can be done in any of a number of locations, such as the home, school, clinic, rehabilitation center, or hospital, provided that all personnel fitting hearing aids have received the necessary training and have access to the results of the recent hearing assessment.

\section{Support for users}

When hearing aids are fitted, proper instructions should be given to users and such caregivers as parents, other family members, teachers, and social workers. Hearing aid users require a "teaming" or "adaptation" period during which repeated instructions and support are provided. This learning period may last from a few weeks to some months. The instruction topics that will need to be covered include: how to use the aid (inserting earmold, wearing the aid, changing batteries, and use of volume control, on/off switch, and any other user controls); encouragement of realistic expectations; when to use and not use the aid; encouragement to continue with learning to use the hearing aid; care and maintenance of the aid (changing batteries, washing the earmold, storage); where and how to obtain new batteries; and troubleshooting (what to do and whom to contact when problems occur with the aid).

Adequate, continued follow-up helps to encourage better use of the hearing aid, provides ongoing support, and deals with problems that may arise. Items to be covered in this period include: hearing tactics (training users to use their residual hearing and the hearing aid more effectively); repetition of instructions on use and care of the aid; replacement due to loss or breakage; attention to the special needs of children (e.g., acceptance of aid, need for more information, and support and other services); establishment of local support groups that use the skills and experience of existing hearing aid users; and links with other services for deaf and hearing-impaired people.

\section{SINOPSIS}

\section{Audífonos y servicios de implantación para países en desarrollo}

De los 250 millones de personas que, según estimaciones, tienen pérdida de la audición y podrían beneficiarse del uso de un audífono, dos terceras partes viven en países en desarrollo. No obstante esta necesidad perentoria, de los audífonos que se fabrican en el mundo, solamente alrededor de uno de cada ocho termina siendo enviado a un país en desarrollo. $Y$ de los audífonos que sí van a parar a países del tercer mundo, la mayoría son demasiado caros para el consumidor ordinario, ya que su costo varía de US\$ 200 a más de US\$ 500. Por añadidura, los países en desarrollo tienen gran escasez de servicios para la colocación adecuada de estos dispositivos y muy pocas personas adiestradas en cómo hacerlo. En vista de la situación, la Organización Mundial de la Salud acaba de emitir directrices para países en desarrollo sobre el uso de audífonos y aparatos afines. Estas nuevas directrices detallan los requisitos para la fabricación de audífonos baratos y de buena calidad y para la provisión de servicios en esos países. La intención es que estos requisitos ayuden a las fabricantes a hacer audífonos a precios bajos y en grandes cantidades con las tecnologías que hay actualmente, procurando reducir su precio a US\$ 10 ó US\$20 por aparato. Los niños con sordera moderada o grave en el oído menos afectado deben recibir atención prioritaria, según las nuevas directrices. 